\title{
Liter per Gram per Minute
}

National Cancer Institute

\section{Source}

National Cancer Institute. Liter per Gram per Minute. NCI Thesaurus. Code C85659.

Liters per gram per minute. 